\title{
Screening of Pea Accessions for Resistance against White Rot of Pea Caused by Sclerotinia sclerotiorum (Lib.) de Bary
}

\author{
Devesh Pathak*, R.U. Khan and Vaibhav Pratap Singh \\ Department of Plant Protection, Faculty of Agricultural Sciences, Aligarh Muslim University, \\ Aligarh, Uttar Pradesh, India-202002 \\ *Corresponding author
}

\section{A B S T R A C T}

Keywords

Screening, disease resistant, Pisum sativum,

Sclerotinia sclerotiorum, White rot.

Article Info Accepted: 21 June 2017 Available Online: 10 July 2017
In this study, 48 pea accessions collected from Indian institute of pulse research, Kanpur, were screened for resistance to Sclerotinia sclerotiorum by two different method viz., cut stem and detached leaf method. The observations of result in cut stem method showed that 15 out of 48 accessions found resistant to white rot, resulted $0-2.5 \mathrm{~cm}$ lesion length, however 26 accessions found tolerant against the pathogen, resulted $2.5-6 \mathrm{~cm}$ lesion length. In this study, 7 accessions out of 48 were found susceptible to Sclerotinia sclerotiorum, resulted 7-14 cm lesion length. However in detached leaf method, four accessions (EC- 329569, EC-296176, P-107-2-1 and) of the 48 accessions screened showed resistant against the pathogen which produce lesion length on leaf between 0.4-0.8 $\mathrm{cm}$, whereas 40 pea accessions were reported to moderately resistant, produced $0.8-3.5 \mathrm{~cm}$ lesion length. Of all the accessions screened, three accessions (PM-9, EC- 329554 and EC329572) were found susceptible which produce $3.5-4.3 \mathrm{~cm}$ lesion length of pathogen infection All the accession screened, EC-329569, ET-45189 and IPF-5-19 were found resistant, while PM- 9, EC- 329554 and EC- 329558 were found susceptible in this study.

\section{Introduction}

Field pea (Pisum sativum L.) is an important pulse crop grown throughout the world including India. The crop plays an important role in human diet providing higher amount of proteins, minerals and essential amino acids particularly lysine (Nawab, et al., 2008) and improving soil health in terms of fertility and sustainability of the cropping patterns. India is one of the largest field pea producers in the world, stands at the fifth place next to France (Javed, et al., 2002) and contributing of area (0.76 m ha), production $(0.84 \mathrm{~m} \mathrm{t})$ with productivity (1.1 t/ha), respectively (Gowda 2015). The pea cultivation is ravaged by several fungal diseases including ascochyta blight (Ascochyta pisi), powdery mildew (Eryisphe pisi), downy mildew (Peronospora viciae f. sp. pisi), septoria blight (Septoria pisi), and white mold (Sclerotinia sclerotiorum), common seed rot (Rhizoctonia solani), seedling damping-off diseases (Pythium spp.) and Common root rots include Fusarium root rot (Fusarium solani f. $s p$. pisi), Aphanomyces root rot (Aphanomyces euteiches), and Fusarium wilt (Fusarium oxysporum f. sp. pisi) (Kraft and Pfleger, 2001; McGee, 2012). Among all fungal pathogen, Sclerotinia sclerotiorum, causing white mould of pea known to be most devastating, cosmopolitan and necrotrophic 
pathogen, attack over 650 species of plants worldwide (Farr and Rossman 2011) and responsible to cause yield losses upto $100 \%$ in favourable condition (Purdy, 1979). The disease is more prevail and damaging in cool and wet seasons of temperate and subtropical regions (Purdy, 1979; Willets and Wong, 1980; Saharan and Mehta, 2008). Initially the symptoms appear as elongated water-soaked lesions on the stem that expand rapidly and also found in leaf and pod. Later the lesions become bleached and necrotic and subsequently develop fluffy white mycelium, which is the most characteristic sign of mycelial infection (Bolton et al., 2006). The affected stem then shred and several grayishwhite to black, spherical and irregular sclerotia appear either in the pith of the affected stem or on the stem surface.

The pathogen is difficult to manage with a single management practise because their survival in soil is too longer and has a wide host range, however, cultural and chemical management tools are either expensive or less effective. Therefore, development of host resistant is one of the most advantageous, sustainable and economical method for effectively managing of this disease (Zhao et al., 2004; Li et al., 2006 and Porter, 2009). The main objective of this experiment was to identify the sources of partial resistance to $S$. sclerotiorum in pea accessions collections that would be help to pea breeders for developing resistance pea cultivars against this pathogen.

\section{Materials and Methods}

A field trial was conducted at Department of Plant Protection, Aligarh Muslim University, Aligarh during rabi seasons 2016-2017 in a sick plot condition.

\section{Inoculum and field experiments}

Forty eight promising entries of pea collected from Indian Institute of Pulse Research,
Kanpur, were screened against Sclerotinia rot. All these accessions were grown in a single row of $3 \mathrm{~m}$ length in augmented design in 3 replications with row to row spacing $30 \mathrm{~cm}$ keeping $10 \mathrm{~cm}$ plant to plant distance. Sclerotinia sclerotiorum isolate ( $\mathrm{Scl} 01)$ isolated in 2016 from Department of Plant Protection, Aligarh Muslim University, Aligarh and pathogenic to pea, was used for inoculations. Sclerotia of the isolate were transferred to Petri dishes containing potato dextrose agar (PDA) and incubated in the dark at $22 \pm 2{ }^{\circ} \mathrm{C}$ until the fungus colonized the agar. Agar plugs containing fungal mycelia were then removed from the leading edge of the expanding colony and transferred again to PDA and incubated in the dark at $22 \pm 2{ }^{\circ} \mathrm{C}$ for 2 days.

\section{Cut stem method}

Mini-agar plugs colonized with mycelia measuring $3 \mathrm{~mm}^{2}$ were cut from the margin of actively growing mycelial colonies and used to inoculate plants. For inoculation, 5 week old plants were selected and main stem of plant horizontally severed with a sterile razor blade $0.5 \mathrm{~cm}$ above either the fourth or fifth node. A single mycelial plug (mycelial-side down) was placed on the cut stem.

\section{Detached leaf method}

The youngest fully expanded trifoliolate leaves of 5-week-old pea plants were cut at the stem, and place into Petri dishes labelled with four layered towel paper at the bottom. Mycelial plugs were placed centred with fungus-side down on one side of the middle trifoliolate leaf between the leaf edge and main leaf vein and slowly pressed to ascertain good contact with the leaf surface. To each Petri dishes, $20 \mathrm{ml}$ of tap water was added, and each plate was wrapped with plastic wrap to maintain humidity. Petri dishes containing inoculated leaves were incubated at $20 \pm 2{ }^{\circ} \mathrm{C}$. The observations of experiment were 
calculated on basis of lesion length $(\mathrm{cm})$ (Kull, 2003) which was developing after the inoculation of pathogen.

\section{Results and Discussion}

The pea accessions screened shown resistant to infection but varied in response to lesion expansion in both methods (Cut stem and detached leaf method). In cut stem-inoculated plants typical water-soaked symptoms of white rot showed 3 days after inoculation. The observations of host response in relation to resistant and susceptibility thus recorded in difference in lesion length of pathogen infection. Fifteen of the 48 accessions screened demonstrated white mould resistance based on mean lesion length which was $2.5 \mathrm{~cm}$ or less, however, 26 pea accessions were considered to be moderately resistant to $S$. Sclerotiorum produced 2.5-6 $\mathrm{cm}$ lesion length. Only six accessions (PM-9,
EC- 329554, EC-329572, EC-329566, HUP-8 and IPFD-6-3) were found susceptible to Sclerotinia sclerotiorum resulted $7-14 \mathrm{~cm}$ lesion length of pathogen infection (Table 1).

In detached leaf method, visible water soaking and leaf necrosis symptoms appear under the plug after $24 \mathrm{~h}$. At $48 \mathrm{~h}$, the watersoaking and necrotic regions reached the leaf margin in some leaves. Four accessions (EC329569, EC-296176, P-107-2-1 and ET45189) of the 48 accessions screened showed resistant against the pathogen which produces lesion length on leaf between $0.4-0.8 \mathrm{~cm}$, whereas 40 pea accessions were reported to moderately resistant, produced $0.8-3.5 \mathrm{~cm}$ lesion length. Of all the accessions screened, three accessions (PM-9, EC- 329554 and EC329572) were found susceptible which produce $3.5-4.3 \mathrm{~cm}$ lesion length of pathogen infection (Table 2).

Fig.1 Reaction of different genotype of pea against white rot caused by Sclerotinia sclerotiorum

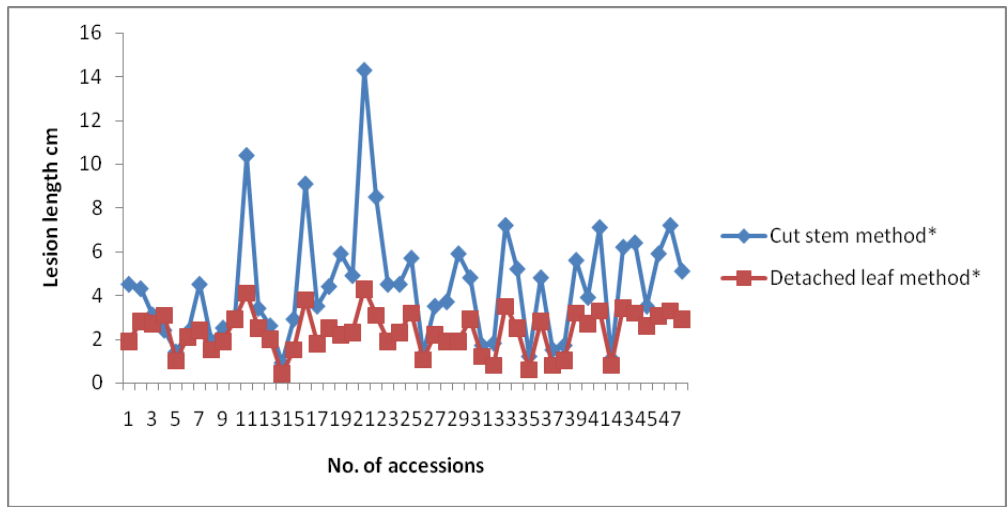

Table.1 Response of pea accessions against Sclerotinia sclerotiorum

\begin{tabular}{|c|c|c|}
\hline \multirow{2}{*}{ Reaction of host plant } & \multicolumn{2}{|c|}{ Lesion length (cm) } \\
\cline { 2 - 3 } & Cut stem method & Detached leaf method \\
\hline Resistant & Less than $2.5 \mathrm{~cm}$ & $0.4-0.8 \mathrm{~cm}$ \\
\hline Moderately resistant & $2.5-6 \mathrm{~cm}$ & $0.8-3.5 \mathrm{~cm}$ \\
\hline Susceptible & $7-14 \mathrm{~cm}$ & $3.5-4.3 \mathrm{~cm}$ \\
\hline
\end{tabular}


Table. 2 Reaction of different accessions of pea against white rot caused by

\begin{tabular}{|c|c|c|c|}
\hline \multirow[t]{2}{*}{ S. No. } & \multirow[t]{2}{*}{ Name of accessions } & \multicolumn{2}{|c|}{$\begin{array}{l}\text { Lesion length }(\mathrm{cm}) \\
\end{array}$} \\
\hline & & Cut stem method* & Detached leaf method* \\
\hline 1 & NIC-11183 & 4.5 & 1.9 \\
\hline 2 & EC-1408 & 4.3 & 2.8 \\
\hline 3 & NIC-18895 & 3.1 & 2.7 \\
\hline 4 & NIC-18905 & 2.4 & 3.1 \\
\hline 5 & EC-18909 & 1.4 & 1.0 \\
\hline 6 & DMR-11 & 2.3 & 2.1 \\
\hline 7 & EC-11208 & 4.5 & 2.4 \\
\hline 8 & NIC-11184 & 1.9 & 1.5 \\
\hline 9 & NIC-57473 & 2.5 & 1.9 \\
\hline 10 & EC-292161 & 3.0 & 2.9 \\
\hline 11 & PM-9 & 10.4 & 4.1 \\
\hline 12 & ET-5122 & 3.4 & 2.5 \\
\hline 13 & EC-329551 & 2.6 & 2.0 \\
\hline 14 & EC-329569 & 0.9 & 0.4 \\
\hline 15 & EC-329571 & 2.9 & 1.5 \\
\hline 16 & EC-329554 & 9.1 & 3.8 \\
\hline 17 & EC-320778 & 3.5 & 1.8 \\
\hline 18 & EC-325280 & 4.4 & 2.5 \\
\hline 19 & EC-329550 & 5.9 & 2.2 \\
\hline 20 & EC-329558 & 4.9 & 2.3 \\
\hline 21 & EC-329572 & 14.3 & 4.3 \\
\hline 22 & EC-329566 & 8.5 & 3.1 \\
\hline 23 & EC-329552 & 4.5 & 1.9 \\
\hline 24 & EC-324129 & 4.5 & 2.3 \\
\hline 25 & P-1541-1 & 5.7 & 3.2 \\
\hline 26 & EC-292167 & 1.3 & 1.06 \\
\hline 27 & EC-292171 & 3.5 & 2.2 \\
\hline 28 & EC41487 & 3.7 & 1.9 \\
\hline 29 & EC-292160 & 5.9 & 1.9 \\
\hline 30 & EC-341787 & 4.8 & 2.9 \\
\hline 31 & P-1-3 & 1.7 & 1.2 \\
\hline 32 & EC-296176 & 1.8 & 0.8 \\
\hline 33 & HUP-8 & 7.2 & 3.5 \\
\hline 34 & KSP-22 & 5.2 & 2.5 \\
\hline 35 & ET-45189 & 1.2 & 0.6 \\
\hline 36 & KSP-21 & 4.8 & 2.8 \\
\hline 37 & P-107-2-1 & 1.5 & 0.8 \\
\hline 38 & EC-584815 & 1.7 & 1.03 \\
\hline 39 & KSP-15 & 5.6 & 3.2 \\
\hline 40 & P-1297-77-1 & 3.9 & 2.7 \\
\hline 41 & IPF-99-25 & 7.1 & 3.3 \\
\hline 42 & IPF-5-19 & 1.1 & 0.8 \\
\hline 43 & IPFD-1-10 & 6.2 & 3.43 \\
\hline 44 & IPFD-99-13 & 6.4 & 3.2 \\
\hline 45 & IPFD-11-5 & 3.5 & 2.6 \\
\hline 46 & IPFD-10-12 & 5.9 & 3.06 \\
\hline 47 & IPFD-6-3 & 7.2 & 3.3 \\
\hline 48 & IPFD-4-9 & 5.1 & 2.9 \\
\hline CD at $5 \%$ & --- & 1.09 & 0.54 \\
\hline $\mathrm{CV} \%$ & $\begin{array}{ll}-- \\
\end{array}$ & 15.12 & 14.25 \\
\hline
\end{tabular}

*Each value is an average of 3 replicates 
Thus it was cleared from the study that all the accession screened, EC-329569, IPF-5-19 and ET-45189 were found highly resistant, while PM- 9, EC- 329554 and EC-329572 were found highly susceptible against the Sclerotinia sclerotiorum (Table 2 and Fig. 1). The development of resistance to $\mathrm{S}$. sclerotiorum in pea is a challenge. Presently breeders are facing the absence of pea genotypes with complete resistance to this pathogen (Blanchette and Auld, 1978; Porter et al., 2009; Porter, 2012). Based on stem lesion advancement data, the following genotypes would be recommended to breeders to improve partial resistance to white mould disease of pea.

\section{References}

Blanchette, B.L., Auld, D.L. 1978. Screening field peas for resistance to white mold. Crop Science 18, 977-9.

Bolton, D. M., Thomma, P.H.J.B and Nelson, D.B. 2006. Sclerotinia sclerotiorum (Lib.) de Bary: biology and molecular traits of a cosmopolitan pathogen. Mol Plant Pathol 7: 1-16.

Farr, D.F and Rossman, A.Y. (2011) Sclerotinia sclerotiorum. In: Fungal Databases, Systematic Mycology and Microbiology Laboratory. United States Department of Agriculture, Agricultural Research Service.

Gowda, C.L.L., Chaturvedi, S.K., Gaur, P.M., Kumar, C.V.S and Jukanti, A.K. (2015). Pulses research and development strategies for india. www.commodityindia.com.

Javaid, A., Ghafoor and Anwar, R. 2002. Evaluation of local and exotic pea (Pisum sativum) germplasm for vegetative and dry grain traits. Pak. J. Bot. 34(4): 419-427.

Kraft, J. and Pfleger, F. (2001).Compendium of pea diseases and pests. 2nd ed. APS Press, the American Phytopathological Society, St. Paul, MN.
Kull, L.S. 2003. Evaluation of Resistance Screening Methods for Sclerotinia Stem Rot of Soybean and Dry Bean. Plant Dis. 87:1471-1476.

Li CX., Li H., Sivasithamparam, K., Fu, T.D., Li, Y.C., Liu, S.Y. and Barbetti, M. J. 2006 Expression of field resistance under Western Australian conditions to Sclerotinia sclerotiorum in Chinese and Australian Brassica napus and Brassica juncea germplasm and its relation with stem diameter. Australian J Agril Res 57: 1131-1135.

McGee, R. 2012. USDA-ARS. Personal communication.

Nawab, N. N., Subhani, G. M., Mahmood K., Shakil, Q. and Saeed, A. 2008. Genetic variability, correlation and path analysis studies in garden pea (Pisum sativum L.). $J$. Agric. Res. 46(4): 333-340.

Porter, L.D., Hoheisel, G., Coffman, V. A. 2009 Resistance of peas to Sclerotinia sclerotiorum in the Pisum core collection. Plant Pathol 58:52-60.

Porter, L. D. 2012. Selection of pea genotypes with partial resistance to Sclerotinia sclerotiorum across a wide range of temperatures and periods of high relative humidity. Euphytica (2012) 186:671-678

Purdy, L. H. 1979. Sclerotinia sclerotiorum: History, diseases, and symptom pathology, host range, geographic distribution, and impact. Phytopathology. 69: 875-880.

Sharma, C.L. and Kapoor, A.S. 1997. Some epidemiological aspects of white rot of pea. Indian Phytopathology, 50 (3): 342-349.

Zhao, J., Peltier, A.J., Meng, J., Osborn, T.C. and Grau, C.R. 2004. Evaluation of Sclerotinia stem rot resistance in oilseed Brassica napus using a petiole inoculation technique under greenhouse conditions. Plant Dis 88: 1033-1039.

\section{How to cite this article:}

Devesh Pathak, R.U. Khan and Vaibhav Pratap Singh. 2017. Screening of Pea Accessions for Resistance against White Rot of Pea caused by Sclerotinia sclerotiorum (Lib.) de Bary. Int.J.Curr.Microbiol.App.Sci. 6(7): 2150-2154. doi: https://doi.org/10.20546/ijcmas.2017.607.252 